\title{
Comment on "An early Late Triassic long-necked reptile with a bony pectoral shield and gracile appendages" by Jerzy Dzik and Tomasz Sulej
}

\author{
JOACHIM SZULC, GRZEGORZ RACKI, and ADAM BODZIOCH
}

Dzik and Sulej (2016) once more show that the Silesian Keuper bone beds are and will continue to be a source of astonishing vertebrate material. At the same time, they stress (2016: 805) that "the age and sedimentological interpretation of the strata continue to be subject to controversy," but their résumé of competing ideas is incomplete and biased in some respects. First of all, Dzik and Sulej (2016) ignore the comprehensive polemical review of the Krasiejów site in Szulc et al. (2015b: 589-595). This omitted paper includes not only "lithostratigraphic correlation with formations of such an age in Germany, as interpreted by these authors" (as claim Dzik and Sulej 2016: 807; a propos, is there an alternative, more reliable interpretation of the German formations?).

First, let us recall a general biostratigraphic principle, propagated as well by Dzik et al. (2008: 19): "Replacements of one fauna by others in single geological profiles are merely a record of local environmental shifts, not of global evolutionary changes." Accordingly, does an occurrence of the phytosaur in an Alpine or Germanic Carnian locality constitute adequate correlative evidence? Doubts on the subject were highlighted by Dzik and Sulej (2007: 24) themselves. The effectiveness of the most renowned marine biozonations results from refined knowledge of full temporal ranges of the taxa. The knowledge accumulated from many densely-sampled sedimentary basins, culminating finally in a sophisticated global compilation of distributions in time and space, paired with phylogenetic trees and migration histories. Hence, while conchostracan data may be more important (cf. revision in Kozur and Weems 2010), the Silesian assemblage appears to contain at least two species known only from this locality (Gregoriusella bocki is close to the "Rhaetian" G. polonica from Lipie Śląskie), and neither preceding nor subsequent microfaunas are known. As emphasized by Nitsch (in Szulc et al. 2015b: 614): "Biostratigraphy of the Keuper has always been a kind of a quiz game that has lost the answer cards (...) Up to now, all groups have their limitations." Respecting this viewpoint, we see all biochronological arguments from Krasiejów favoring a late Carnian date (even if seldom explained as "probable") as suggestive but far from conclusive, especially since the Keuper subtropical habitats were controlled by the northward drift of Laurasia.

Szulc et al. (2015b) offer litho-, chemo-, and climatostratigraphic data favoring an early Norian date. However, in fact they approve only correlation of the bone-rich Steinmergel (= Arnstadt)-type Krasiejów section with the Steinmergel-type Drawno beds of the subsurface Polish Basin succession (= lower Jarkowo beds in recent schemes), already proposed by Dzik et al. (2000) themselves. The Jarkowo beds have been repeatedly palynostratigraphically dated as basal Norian (Fijałkowska-Mader et al. 2015: fig. 6). A puzzling correlative divergence between the surely Carnian Upper Gypsum Beds (= Weser Formation) of western Germany, implied from biostratigraphy, and the Polish Norian unit (overlying the gypsum-bearing Keuper) was indeed without any attempt at an explanation (see Dzik et al. 2000: 228; Dzik and Sulej 2007: 22). The most recent account of the dilemma is given by Lucas (2015: 727), who still prefers late Carnian dating for this site, but adds: "this correlation of the Krasiejów level is confounded by disagreements over correlation of the marine Carnian-Norian boundary to nonmarine strata. Indeed, the possibility that the Krasiejów tetrapods fill a gap in the early Norian record of tetrapods merits consideration." The Norian record in the Germanic Basin, notably missing due to the main Eo-Cimmerian hiatus, corresponding to several million years, leads to manifold concerns about any correlation on paleontological grounds across the Carnian-Norian transition.

There is general agreement that the Krasiejów variegated succession displays fabrics representative of alternating fluvial and pedogenic processes taking place in the semiarid, trade-wind climatic zone. The region was dominated by low-relief gilgai microrelief, characterized by alternating mounds and depressions, influenced by accidental heavy storm runoffs during wet seasons (Szulc 2005; compare Bilan 1975; Dzik et al. 2000; Dzik and Sulej 2007; Bodzioch and Kowal-Linka 2012). Thus, its critical character includes the rapid lateral pinchout of the 0.5 -m-thick bone bed in the Krasiejów clay pit (see also borehole data in Bilan 1975), in opposition to the predicted lateral continuity of the given horizon so typical of lacustrine basins (repeatedly asserted since Dzik et al. 2000; Dzik and Sulej 2007, 2016: 805-807). But what, in this context, can be the meaning of the enigmatic (from a sedimentological viewpoint) phrase "periodic ponding at a lake shore"? The gray, fossil-bearing claystone layer is actually swamp sediment, underbedded by an impermeable vertisol and bounded by elevated ridges (and mostly graded upward into a reddish regolithic soil complex deposited during the next dry period; compare Szulc 2005; Bodzioch and Kowal-Linka 2012). 
This "great lake model" in turn is an illusory basis for the diverse paleobiological speculations of Dzik and Sulej (2016). The introductory thesis ("The adaptation to an aquatic lifestyle of the majority of the fossilized inhabitants of the Krasiejów lake argues against the scenario raised by Bodzioch and KowalLinka (2012), who proposed that this was a periodic pond that quickly dried and filled with sediment") has to be questioned on the grounds of logic and available data. Of course, the aquatic animals discussed undoubtedly lived and perhaps died in water, but this occurred in many unknown aquifers in the episodic braided fluvial system (why not persisting locally for a severalyear period?), and, as a material question, this lifestyle does not indicate the existence of any lake. This has been proven on the grounds of the co-occurrence of bones that must have been primarily buried in different early diagenetic environments. This means that the remains forming the main time-averaged bone accumulation were redeposited from a large area and that the extensive Krasiejów depression, composed of complex evaporated post-flood ponds, was only the final place of their catastrophic burial (Bodzioch and Kowal-Linka 2012). The formal logical fallacy concerns the classical circulus vitiosus: the authors write "inhabitants of the Krasiejów lake", which implies that "the Krasiejów lake existed" (the first premise of unknown value, i.e., whether true or false) and "there were animals living in the Krasiejów lake" (the similar second premise); then, the authors describe adaptations to the aquatic lifestyle of "the inhabitants of the Krasiejów lake", which is offered as proof of the final conclusion "the Krasiejów lake existed" and, simultaneously, a false inference from the first premise. In this context, the principal disinformation resides in the statement that "According to Bodzioch and Kowal-Linka (2012) the early diagenetic history [of bones] was outside the aquatic environment and that they were subsequently transported to the lacustrine environment." The italicized (by us) phrase was never used by Bodzioch and Kowal-Linka (2012). And the last, but not least: in the description of the new species, its type horizon is defined merely as probably late Carnian "lacustrine bed", even though Dzik and
Sulej (2016) cite the paper of Szulc et al. (2015a) explaining the precise position of the Krasiejów bone-bearing level in the formal lithostratigraphic scheme of the Silesian Keuper (i.e., within the Grabowa Formation, an equivalent of the Weser and Arnstadt formations).

\section{References}

Bilan, W. 1975. The Rhaetic profile in Krasiejów near Opole [in Polish with English summary]. Zeszyty Naukowe AGH, Geologia 1 (3): 13-19.

Bodzioch, A. and Kowal-Linka, M. 2012. Unraveling the origin of the Late Triassic multitaxic bone accumulation at Krasiejów (S Poland) by diagenetic analysis. Palaeogeography, Palaeoclimatology, Palaeoecology 346-347: 25-36.

Dzik, J. and Sulej, T. 2007. A review of the early Late Triassic Krasiejów biota from Silesia, Poland. Palaeontologia Polonica: 64: 3-27.

Dzik, J. and Sulej, T. 2016. An early Late Triassic long-necked reptile with a bony pectoral shield and gracile appendages. Acta Palaeontologica Polonica 61: 805-823.

Dzik, J., Niedźwiedzki, G., and Sulej, T. 2008. Surprising culmination of the age of mammal-like reptiles [in Polish]. Ewolucja 3: 1-21.

Dzik, J., Sulej, T., Kaim, A., and Niedźwiedzki, R. 2000. Late Triassic graveyard of large Triassic tetrapods in the Opole Silesia [in Polish with English summary]. Przeglad Geologiczny 48: 226-235.

Fijałkowska-Mader, A., Heunisch, C., and Szulc, J. 2015. Palynostratigraphy and palynofacies of the Upper Silesian Keuper, Poland. Annales Societatis Geologorum Poloniae 85: 637-661.

Kozur, H.W. and Weems, R.E. 2010. The biostratigraphic importance of conchostracans in the continental Triassic of the northern hemisphere. In: S.G. Lucas (ed.), The Triassic Timescale. Geological Society of London Special Publication 334: 315-417

Lucas, S.G. 2015. Age and correlation of Late Triassic tetrapods from southern Poland. Annales Societatis Geologorum Poloniae 85: 627-635.

Szulc, J. 2005. Sedimentary environments of the vertebrate-bearing Norian deposits from Krasiejów, Upper Silesia (Poland). Hallesches Jahrbuch der Geowissenschaften 19: 161-170.

Szulc, J., Racki, G., and Jewuła, K. 2015a. Key aspects of the stratigraphy of the Upper Silesian middle Keuper, southern Poland. Annales Societatis Geologorum Poloniae 85: 557-586.

Szulc, J., Racki, G., Jewuła, K., and Środoń, J. 2015b. How many Upper Triassic bone-bearing levels are there in Upper Silesia (southern Poland)? A critical overview of stratigraphy and facies. Annales Societatis Geologorum Poloniae 5: 587-626.

Joachim Szulc [joachim.szulc@uj.edu.pl], Institute of Geological Sciences, Jagiellonian University, ul. Oleandry 2a, 30-063 Kraków, Poland. Grzegorz Racki [grzegorz.racki@us.edu.pl], Faculty of Earth Sciences, University of Silesia at Katowice, ul. Będzińska 60, 41-200 Sosnowiec, Poland. Adam Bodzioch [abodzioch@uni.opole.pl], Department of Biosystematics, Opole University, ul. Oleska 22, 45-052 Opole, Poland.

Received 10 February 2017, accepted 10 April 2017, available online 16 May 2017.

Copyright (c) 2017 J. Szulc et al. This is an open-access article distributed under the terms of the Creative Commons Attribution License (for details please see http://creativecommons.org/licenses/by/4.0/), which permits unrestricted use, distribution, and reproduction in any medium, provided the original author and source are credited. 